\title{
Sediment discharge and storage over the last deglacial highstand period on the central Vietnam shelf off Nha Trang
}

\author{
Bui Viet DUNG ${ }^{1, *}$, Karl STATTEGGER ${ }^{2,3}$, Nguyen Van KIEU ${ }^{1,4}$, Nguyen Trung THANH ${ }^{5}$, Bui Xuan \\ THONG $^{6}$, Pham Nguyen $\mathrm{Ha} \mathrm{VU}^{7}$, Ha Quang MAN ${ }^{8}$ and Pham Hong TRANG ${ }^{9}$ \\ 1 Vietnam Petroleum Institute, Petrovietnam, 173 Trung Kinh, Hanoi, Vietnam \\ 2 Kiel University, Institute of Geosciences, D-24118 Kiel, Germany \\ 3 Adam Mickiewicz University, ul. Wieniawskiego 1, 61-712 Poznań, Poland \\ 4 AGH University of Science and Technology, al. A. Mickiewicza 30, 30-059 Kraków, Poland \\ 5 Vietnam Academy of Science and Technology, Institute for Marine Geology and Geophysics, 18 Hoang Quoc Viet, Hanoi, \\ Vietnam \\ 6 Institute of Oceanography and Environment, 132 Nguyen Khuyen, Van Mieu, Dong Da, Hanoi, Vietnam \\ 7 University of Science, Hanoi National University, 334 Nguyen Trai, Thanh Xuan, Hanoi, Vietnam \\ 8 Petrovietnam Exploration Production Corporation, 117 Tran Duy Hung, Cau Giay, Hanoi, Vietnam \\ 9 School of Civil Engineering, Asian Institute of Technology, P. O. Box 4, Klong Luang, Pathuthani 12120, Thailand
}

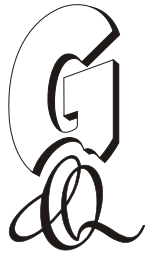

Dung, B.V., Stattegger, K., Kieu, N.V., Thanh, N.T., Thong, B.X., Vu, P.N.H., Man H.Q., Trang, P.H., 2019. Sediment dis-
charge and storage over the last deglacial highstand period on the central Vietnam shelf off Nha Trang. Geological Quarterly, 63 (2): 395-406, doi: 10.7306/gq.1475

Associate editor: Anna Wysocka

A sediment budget for the central Vietnam shelf off Nha Trang over the last deglacial Holocene highstand period has been investigated on the basis of shallow seismic and sediment core data and empirical equations. The annual suspended sediment discharge to the Nha Trang shelf ranges from: 4.3 to $5.4 \mathrm{Mt} / \mathrm{year}$. Estimates based on published empirical equations suggest that the sediment discharge by three main local mountainous rivers (the Cai, Dinh and Van Phong rivers) that enter the Nha Trang shelf ranges between 1.7 and $4 \mathrm{Mt} / \mathrm{year}$, which implies that the local rivers discharge approximately $75 \%$ of the total annual sediment input to the shelf. The annual sediment supply of the Cai River is approximately 2 and 6 times higher than that of the Dinh and Van Phong rivers, respectively. The highstand sediment depocentre of the Nha Trang shelf is mostly attached to the local river outflows, indicating their importance as the principal sediment supply sources to the shelf. Additional sources of sediment supply to the Nha Trang shelf can probably be related to along-shore transport from the nearby shelves. Calculations based on seismic and sediment core data indicate that the net sediment volume storage on the Nha Trang shelf is approximately $2.15 \mathrm{Mt} / \mathrm{year}$. Approximately $50 \%$ of the total sediment yield supplied to the shelf is probably transported along-shore to the south. The sediment budget model for highstand deposits on the Nha Trang shelf is typical for a small mountainous river basin, which is significantly different from that of the large river delta systems in Vietnam such as the Mekong and Red rivers where $90 \%$ of the river sediments are captured on the delta plain/subaqueous part and only $10 \%$ of the river sediments are transported to the nearby shelf. In contrast, most of the sediments supplied by small mountainous rivers off Nha Trang are transported to the mid-shelf, forming a shore-parallel mud depocentre.

Key words: sediment budget, Nha Trang shelf, central Vietnam, Holocene highstand, sequence stratigraphy.

\section{INTRODUCTION}

On the global scale, small mountainous rivers with drainage basins $<104 \mathrm{~km}^{2}$ are considered to account for half of modern

\footnotetext{
* Corresponding author, e-mail: buivietdungspt@yahoo.com; dungbv@vpi.pvn.vn
}

Received: August 22, 2018; accepted: February 15, 2019; first published online: May 31, 2019 sediment discharge to the ocean (Milliman and Syvitski, 1992). Hence, the importance of studying the flux and fate of sediment discharge to the oceans from such mountainous rivers with small drainage basins has been emphasized by many researchers (e.g., Milliman and Syvitski, 1992; Milliman, 1995; Liu et al., 2004; Schimanski and Stattegger, 2005a). These studies indicated that these small river basins have high sediment yields, low sediment storage capacity and they often discharge directly to the adjacent shelf. For example, small rivers draining mountainous areas in Papua New Guinea and Taiwan discharge annually 1700 and 100 million tons of suspended sedi- 


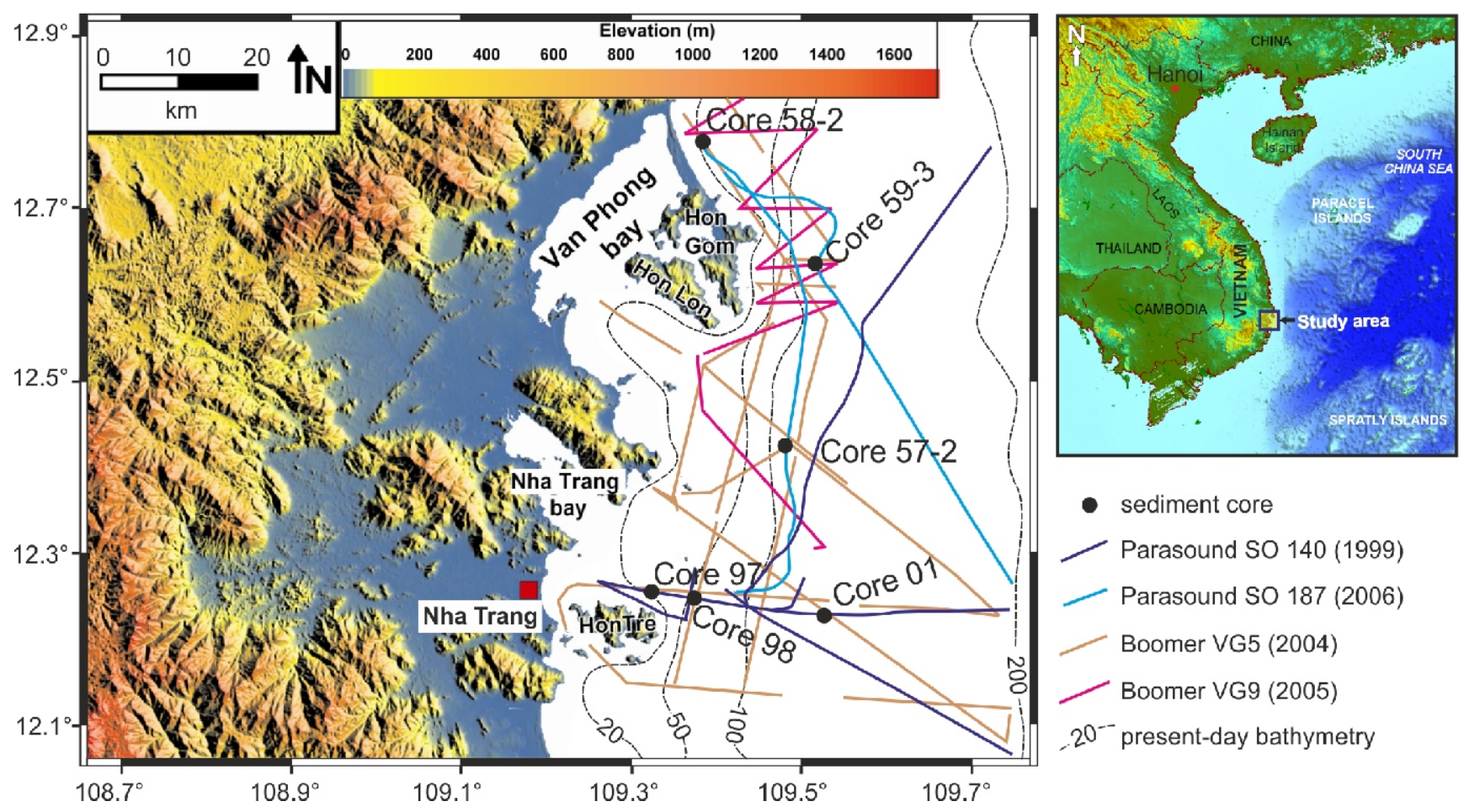

Fig. 1. Map of Nha Trang shelf with modern bathymetry and available subsurface data (adapted from Bui et al., 2014)

Elevation data of the land part is extracted from Shuttle Radar Topography Mission (SRTM) digital elevation models (http://srtm.usgs.gov/)

ment per year (Mt/year), respectively. In Vietnam, the Red River delta in the north discharges $130 \mathrm{Mt} / \mathrm{year}$, and the Mekong River delta in the south discharges $160 \mathrm{Mt} / \mathrm{year}$ to the South China Sea (Milliman and Syvitski, 1992). Previous studies have also suggested that $144 \mathrm{Mt} /$ year and $110 \mathrm{Mt} /$ year are trapped on the Mekong and Red River deltas, respectively ( $\mathrm{Ta}$ et al., 2001; Schimanski and Stattegger, 2005b). This implies that only some $10 \%$ of the total sediment supplied from these two large rivers is transported to the Vietnam shelf. The central shelf of Vietnam is drained by numerous small mountainous rivers that have annually discharged 40-100 Mt/year to the sea during the Holocene Epoch (Schimanski and Stattegger, 2005b). Due to the short distances between sediment sources and sinks, most of the sediments in this region are discharged directly to the shelf. Approximately $20-40 \mathrm{Mt} /$ year is stored on the central Vietnam shelf, and the rest is transported offshore or along-shore (Schimanski and Stattegger, 2005b).

In this study, we will focus on the narrow continental shelf off Nha Trang in southern central Vietnam where shallow seismic profiles and sediment cores are available (Fig. 1). The objectives of this study are to:

- estimate the rate of sediment discharge and storage on the Nha Trang shelf over the past 8000 years;

- quantify the contributions of different local rivers as sediment suppliers to the shelf.

\section{REGIONAL SETTING}

The Nha Trang shelf is located on a passive continental margin that is bordered by the Vietnamese coastline to the west and the South China Sea (SCS) to the east (Fig. 1). The continental shelf off Nha Trang is narrow and steep ( $\sim 40 \mathrm{~km}$ wide)
(Fig. 1). There are two embayments in the study area: Van Phong in the northern part and Nha Trang in the centre. The study area is dominated by a semi-diurnal to diurnal tide regime with tidal amplitudes of $0.4 \mathrm{~m}$ at neap tide and $2.5 \mathrm{~m}$ at spring tide (Hanoi Marine Hydro Meteorological Center, 2004). The average wave height in this area ranges from 0.5 to $2.0 \mathrm{~m}$ during fair-weather times and can reach up to $7.5 \mathrm{~m}$ during storm conditions (Tran et al., 2004). Long-term monitoring data (1985-1995) collected at the Nha Trang station reveal an average temperature of $27^{\circ} \mathrm{C}$ (Emch et al., 2008). Rainfall in Nha Trang shows a wide range of variation between the dry and rainy seasons from 0.1 to $549.2 \mathrm{~mm} /$ month (Emch et al., 2008). Most of the sediments supplied are transported to the nearby continental shelf by small and short mountainous rivers that originate in the up to $1700 \mathrm{~m}$ high mountains and drain a region of high relief (Fig. 2). There are three rivers entering the Nha Trang shelf: the Cai, Dinh and Van Phong rivers (Fig. 2). The amount of sediment being discharged to the shelf is strongly seasonally driven. Szczuciński et al. (2005) found that the sedimentation in the dry season (January to August) is insignificant in Nha Trang bay. The major portion of the sediment is delivered to the shelf during the wet season (September to December). The study by Nguyen (2004) suggests that approximately $70 \%$ of the sediments are transported to the shelf during short periods of the rainy season and $30 \%$ in the dry season. It was also shown that significant sediment volumes in this region are transported generally southwards by along-shore currents while only a small part is transported offshore (Trinh et al., 1979; Bui and Le, 2000; Nguyen et al., 2000a, b; Nguyen and Tong, 2000). Sediment supply to the Nha Trang shelf is therefore considered to be either from the northern shelf by southwards along-shore transport, or by local mountainous rivers. 


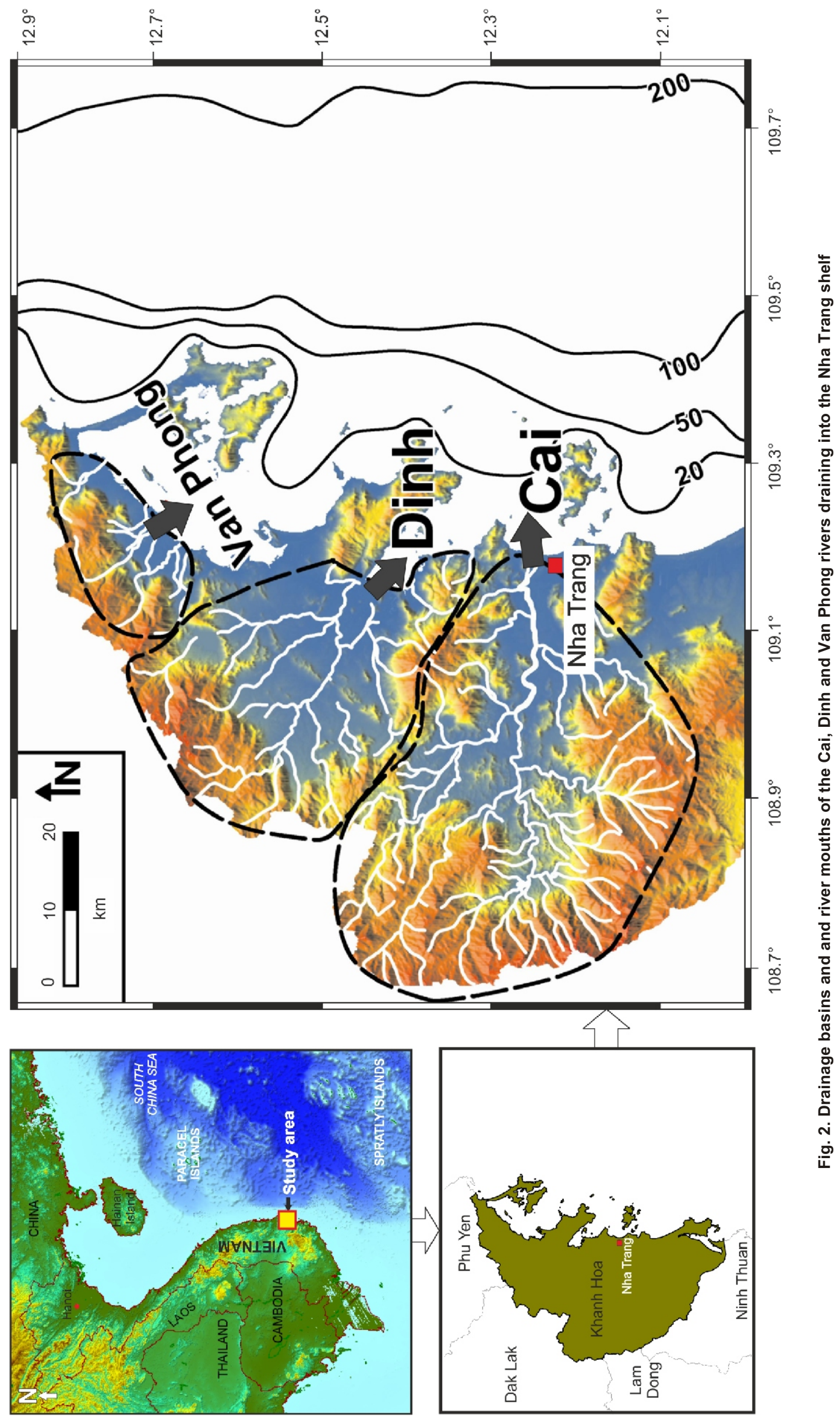




\section{METHODOLOGY AND DATA}

Sediment flux to the coastal zone is controlled by many factors including basin area, relief, temperature, runoff, lithology, and human activities (Syvitski and Milliman, 2007). There are several models, which can be used to quantify the influences of these factors to the long-term flux of sediment delivered by rivers (Schimanski and Stattegger, 2005a; Syvitski and Milliman, 2007). In this study, we calculate sediment fluxes from the local rivers using published models (Schimanski and Stattegger, 2005a; Syvitski and Milliman, 2007). These models can predict the long-term sediment flux delivered by rivers but they do not predict the episodicity of this delivery (Syvitski and Milliman, 2007). The river basins surrounding the Nha Trang shelf are divided into three groups based on the river/stream distribution: the Cai, Dinh and the Van Phong River basins (Fig. 2). To calculate the sediment loads of rivers draining the Nha Trang shelf, we used Shuttle Radar Topography Mission (SRTM) digital elevation models (http://srtm.usgs.gov/) to determine the area and maximum elevation of the drainage basin (Fig. 1). The sediment discharges from the river basins are extracted from the published literature (Barthel et al., 2009). Equations representing the relationship between sediment flux and local geographical/geological factors are shown in the following part.

In addition, high-resolution seismic and sediment core data have been used to identify sediment storage on the shelf over the last deglacial highstand period (Figs. 1, 3 and 4). Seismic data were acquired with two different sound-sources: Boomer and Parasound. Most of the seismic profiles are located at water depths between 20 and 200 m (Fig. 1). The Boomer system (EG\&G Uniboom) is a single channel system that includes an electrical energy supplier and an electromagnetic transducer that transforms the discharged energy to electro-dynamic acoustic pulses. The Boomer source produces a wide bandwidth working frequency with the main range of 0.3 to $11 \mathrm{kHz}$ resulting in a typical penetration of 20 to $100 \mathrm{~m}$ below the seabed. Band-pass frequency filtering of $0.5-7 \mathrm{kHz}$ was applied to the Boomer data. Parasound is a hull-mounted system that combines a narrow beam echosounder with a sub-bottom profiler. The system is operated with a fixed primary frequency of $18 \mathrm{kHz}$ and a secondary primary frequency variable from $20.5-23.5 \mathrm{kHz}$. Both primary frequencies are transmitted simultaneously in a narrow beam. The constructive interference of these frequencies allows generation of a working frequency within the beam of $2.5-5.5 \mathrm{kHz}$ (Grant and Schreiber, 1990). Parasound data was processed and presented by Sent software.

Seismic data was interpreted on the basis of sequence stratigraphic concepts (Catuneanu, 2002, 2009). The seismic units were identified and distinguished from one another by their reflection continuity, amplitude, frequency and configuration (Bui et al., 2014). The seismic surfaces interpreted were then calibrated by sediment core data. Gravity cores taken at selected sites were analysed by sedimentological and geochemical methods (Wiesner, 1999; Schimanski and Stattegger, 2005a; Wiesner, 2006). The cores come from varying water depths between 23.8 to $134 \mathrm{~m}$ (Fig. 4). Radiocarbon ages were determined by accelerator mass spectrometry (AMS; Fig. 4). The Late Pleistocene-Holocene sequence stratigraphic model of the shelf off the Nha Trang area is subdivided into four systems tracts (Bui et al., 2014). This study only focuses on the highstand systems tract of the Nha Trang shelf. Sequence stratigraphic interpretation and an isopach map of the highstand deposits on the Nha Trang shelf are adapted from a previous study (Bui et al., 2014).

\section{CALCULATION OF SEDIMENT LOADS FROM THE LOCAL RIVER}

$$
\text { FIRST APPROACH }
$$

Information about paleo-sediment flux on the central Vietnam shelf is very poor. The first attempt to estimate the discharge of sediment on the central Vietnam shelf was carried out using denudation rates (Schimanski and Stattegger, 2005a). The estimated annual sediment flux for the whole central Vietnam shelf based on the following equation [1] suggested 40-100 Mt/year:

$$
\begin{gathered}
\text { Sediment flux }[\mathrm{t} / \mathrm{yr}]=\text { denudation rate }\left[\mathrm{m} / 10^{6} \mathrm{yr}\right] \times \\
\text { rock density }\left[\mathrm{t} / \mathrm{m}^{3}\right] \times \text { area }\left[10^{4} \mathrm{~m}^{2}\right]
\end{gathered}
$$

Using the same procedure for the Nha Trang area, we can roughly estimate the annual sediment supply for this area as 1.64-4.08 Mt/year (Table 1).

\section{SECOND APPROACH}

In this approach, we calculate long-term average suspended sediment discharging to the shelf based on the BQART equations [2] and [3] for $T \geq 2^{\circ} \mathrm{C}$ (Syvitski and Milliman, 2007):

$$
\begin{gathered}
Q s=\omega B\left(\frac{Q}{Q_{0}}\right)^{0.31} A^{0.5} R T \\
B=L\left(1-T_{e}\right) E_{h}
\end{gathered}
$$

where: $Q s$ - the long-term average sediment load [Mt/y], $A$ - the drainage area $\left[\mathrm{km}^{2}\right], R$ - the maximum elevation in the drainage ba$\sin [\mathrm{km}], T$ - the basin-averaged temperature $\left[{ }^{\circ} \mathrm{C}\right], \mathrm{Q}$ - the long-term average discharge, $Q_{0}=1\left[\mathrm{~km}^{3} / \mathrm{y}\right]$ is a reference value introduced to form a nondimensional ratio of long-term average discharge, and the constant $\omega=0.0006 \mathrm{Mt} / \mathrm{y}^{-1}{ }^{0} \mathrm{C}^{-1} \mathrm{~km}^{-2}$. The uncertainty in calculating sediment discharge from this equation is the variable $B$, which expresses the human impact factor. $B$ depends on lithological erodibility $(L)$, trapping efficiency of reservoirs and lakes $\left(T_{e}\right)$ and the human impact soil erosion factor $\left(E_{h}\right)$.

Each of these parameters shows a wide range of variation depending on both time and space (Syvitski and Milliman, 2007). Thus, instead of estimating a single parameter, we use the calculation from the first approach (Table 1) as the standard value and vary $B$ until the results from both calculations fit each other. This procedure has been applied effectively for the Adriatic Sea (Brommer, 2009). As a result, we can derive the $B$ value as ranging from $0.6-1.4$ (Table 2). The average sediment discharges from the Cai and Dinh basins are extracted from the published literature (Barthel et al., 2009). Sediment discharge from Van Phong basin is inversely estimated by using the above value of the $B$ variable and the calculated sediment load in Table 1.

The results of calculated sediment supply to the Nha Trang shelf from the above two equations are essentially identical and they indicate that the discharge of sediment by the three main local 

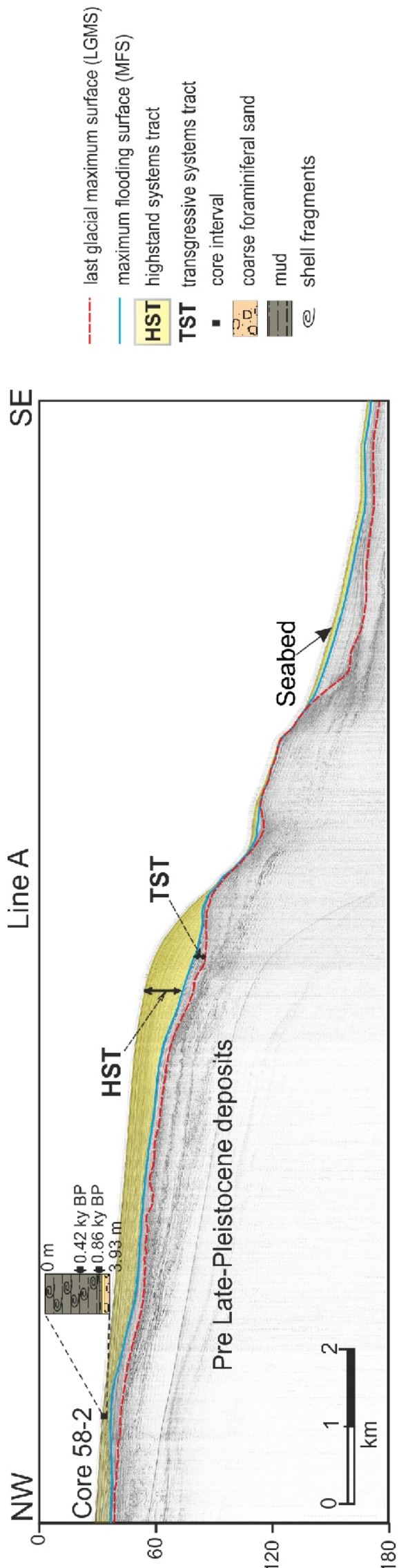

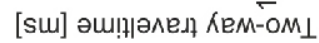
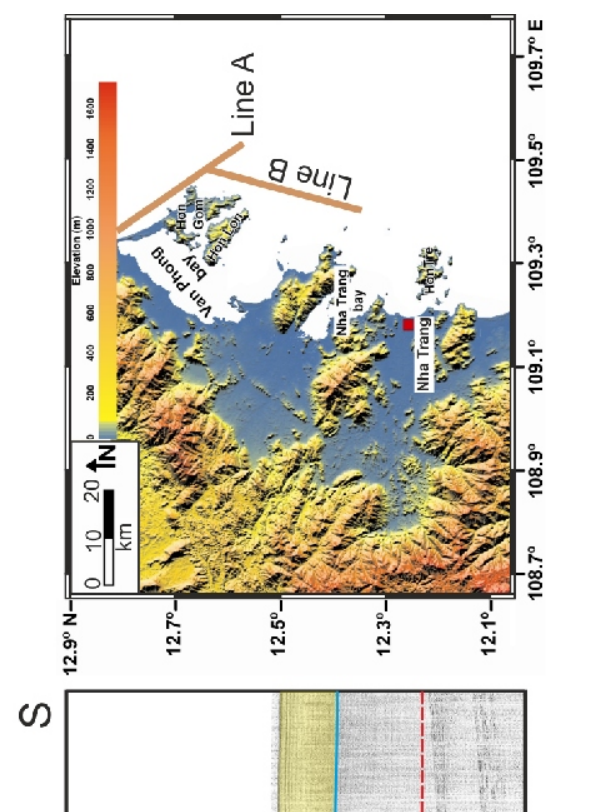

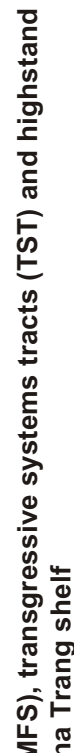

$\stackrel{\Im}{\overrightarrow{3}}$

造

紊蕰

कs

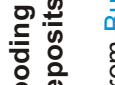

$\stackrel{5}{\circ}$

เ

尔

$\stackrel{9}{=}$

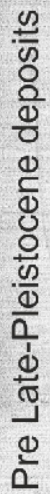

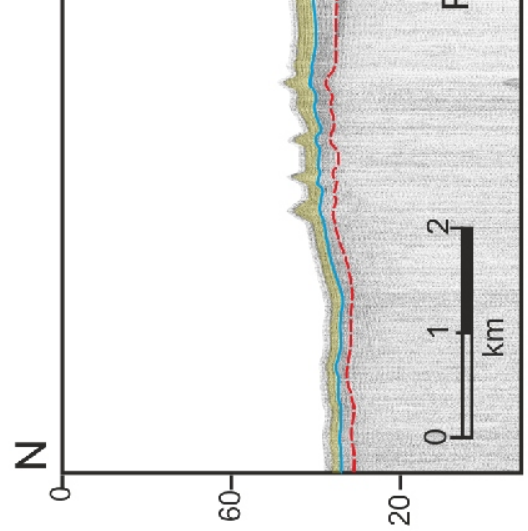

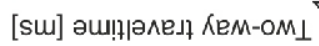

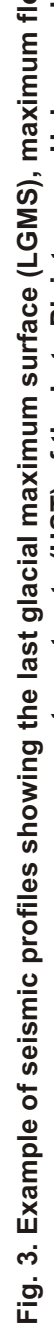

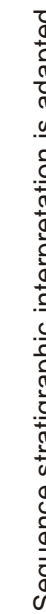

离

के

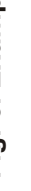



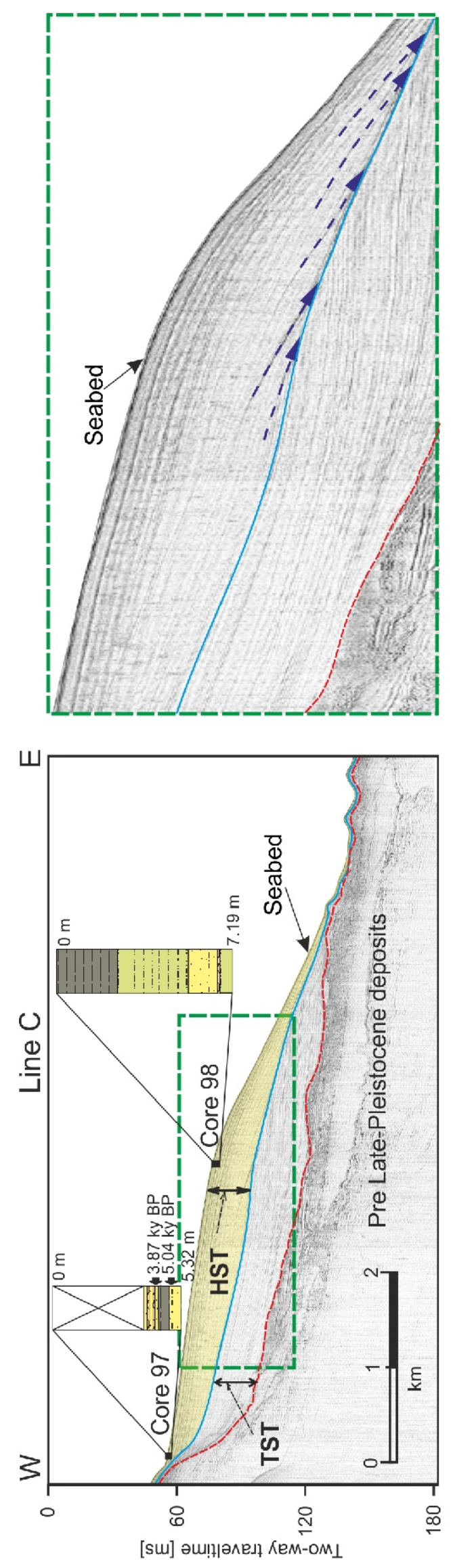
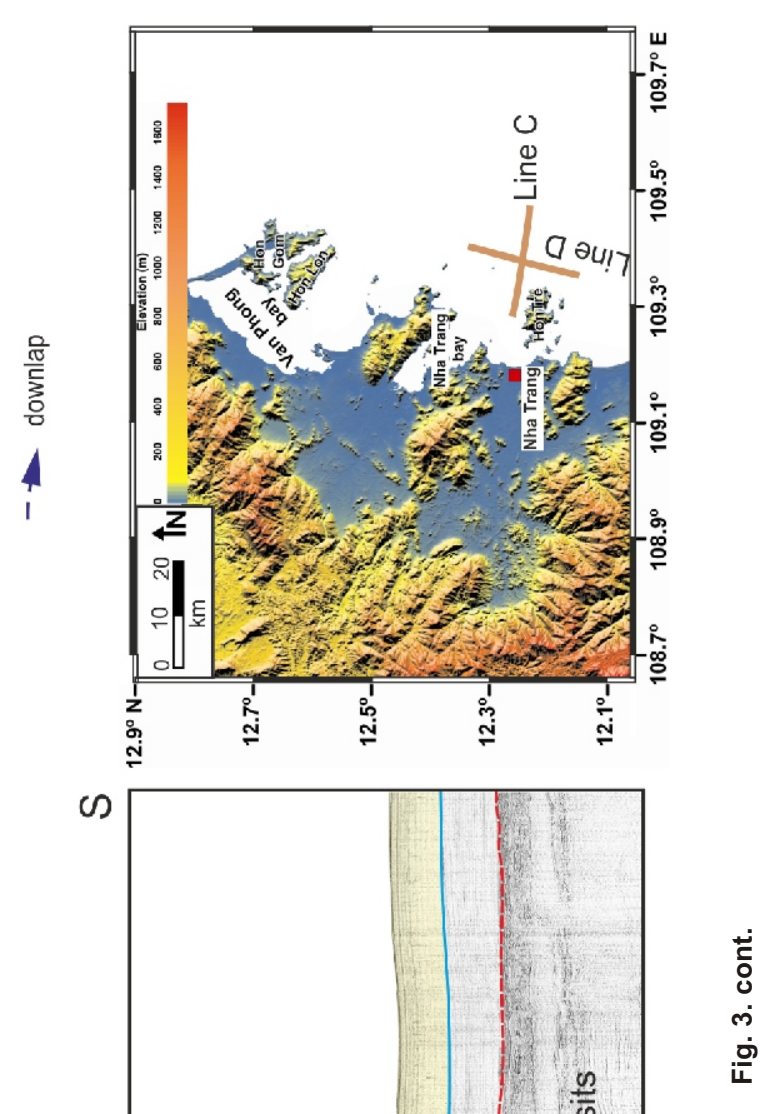

¿ேं
ஸ்
ஸ் 


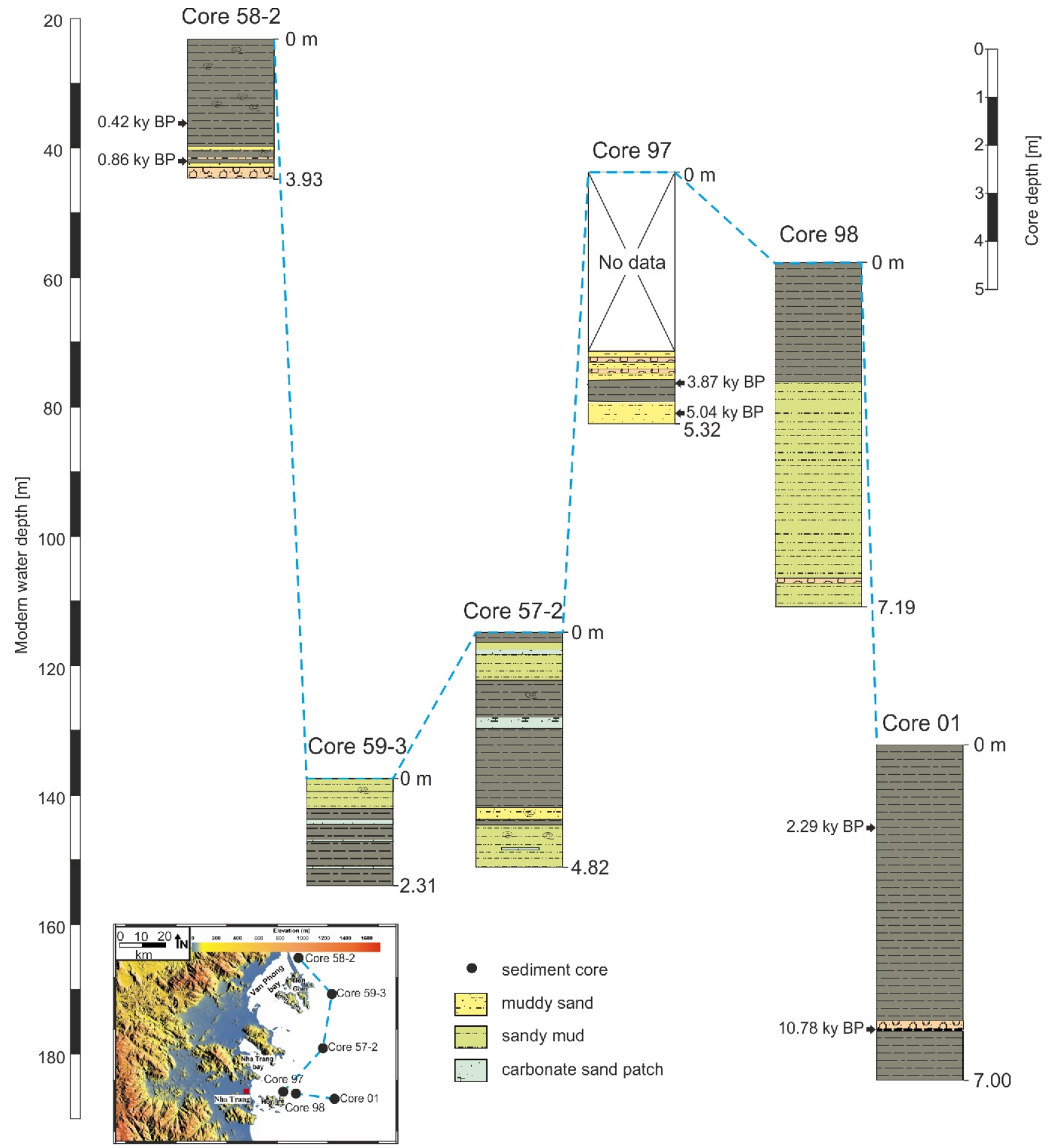

Fig. 4. Sedimentary characteristics (X-ray logs and core description) and AMS- ${ }^{14} \mathrm{C}$ ages of deglacial highstand deposits from gravity cores according to modern water depths on the Nha Trang shelf (Wiesner, 1999, 2006; Schimanski and Stattegger, 2005a)

Other explanations as in Figure 3 
Input parameters and sediment load of three main basins from denudation rate data

\begin{tabular}{|l|c|c|c|c|c|}
\hline River basin & $\begin{array}{c}\text { Average } \\
\text { denudation rate } \\
{\left[\mathrm{m} / 10^{6} / \mathrm{y}\right]}\end{array}$ & $\begin{array}{c}A \\
{\left[\mathrm{~km}^{2}\right]}\end{array}$ & $\begin{array}{c}\text { Rock } \\
\text { density } \\
{\left[\mathrm{t} / \mathrm{m}^{3}\right]}\end{array}$ & $\begin{array}{c}\text { Flux } \\
{\left[10^{6} \mathrm{t} / \mathrm{y}\right]}\end{array}$ & $\begin{array}{c}\text { Flux } \\
{\left[10^{-5} \mathrm{~km}^{3} / \mathrm{y}\right]}\end{array}$ \\
\hline Cai & $200-500$ & 1900 & 2.5 & $0.95-2.37$ & $36-91$ \\
\hline Dinh & $200-500$ & 1100 & 2.5 & $0.55-1.37$ & $21-52$ \\
\hline Van Phong & $200-500$ & 270 & 2.5 & $0.14-0.34$ & $5.2-13$ \\
\hline Total & & & & $1.64-4.08$ & $62-156$ \\
\hline
\end{tabular}

Explanations as in equations [2] and [3]

Table 2

Input parameters and sediment load of three main basins from the BQART equation

\begin{tabular}{|l|c|c|c|c|c|c|c|c|}
\hline River basin & $\begin{array}{c}Q \\
{\left[\mathrm{~km}^{3} / \mathrm{y}\right]}\end{array}$ & $\begin{array}{c}A \\
{\left[\mathrm{~km}^{2}\right]}\end{array}$ & $\begin{array}{c}R \\
{[\mathrm{~km}]}\end{array}$ & $\begin{array}{c}T \\
{\left[{ }^{0}\right]}\end{array}$ & $\begin{array}{c}\mathrm{\omega} \\
{\left[\mathrm{Mt}^{-10}\right.} \\
\mathrm{C}^{-1} \\
\left.\mathrm{~km}^{2}\right]\end{array}$ & $B$ & $\begin{array}{c}Q S \\
{\left[10^{6} \mathrm{t} / \mathrm{y}\right]}\end{array}$ & $\begin{array}{c}Q s \\
{\left[10^{-5} \mathrm{~km}^{3} / \mathrm{y}\right]}\end{array}$ \\
\hline Cai & 2.46 & 1900 & 1.8 & 27 & 0.0006 & $0.6-1.4$ & $1-2.35$ & $38-90$ \\
\hline Dinh & 0.68 & 1100 & 1.9 & 27 & 0.0006 & $0.6-1.4$ & $0.54-1.27$ & $21-48$ \\
\hline Van Phong & 0.34 & 270 & 1.5 & 27 & 0.0006 & $0.6-1.4$ & $0.17-0.4$ & $6.6-15$ \\
\hline Total & & & & & & & $1.71-4.02$ & $65.6-153$ \\
\hline
\end{tabular}

Explanations as in equations [2] and [3]

mountainous river basins (of the Cai, Dinh and Van Phong rivers) ranges from 1.7 to $4 \mathrm{Mt} /$ year. The proportions of sediment supply to the shelf of the three local rivers in this region are as follows: the Cai $60 \%$; the Dinh $30 \%$ and the Van Phong $10 \%$.

CALCULATION OF SEDIMENT STORAGE AND DISCHARGE TO THE SHELF DURING THE DEGLACIAL HIGHSTAND PERIOD

SEISMIC FACIES AND SEDIMENTARY CHARACTERISTICS OF THE HIGHSTAND SYSTEM TRACT (HST)

The HST on the Nha Trang shelf is identified as the first seismic unit below the seabed (Fig. 3). It is bounded at the top by the modern seabed and the maximum flooding surface (MFS) at the base (Bui et al., 2014). The MFS on the Nha Trang shelf is characterized by a moderately continuous reflection on seismic profiles (Fig. 3). On the mid-shelf, it appears on seismic profiles as a clear boundary of the lower backstepping onlap and upper seaward downlapping reflectors (Fig. 3). Six sediment gravity cores taken on the Nha Trang shelf reveal the sedimentary characteristics of highstand deposits (Fig. 4). Only sediment core 01 penetrates to the lower transgressive deposits (Fig. 4). Most of the cores have a muddy composition and low sand content (Fig. 4). Two radiocarbon dates of sediment core 58-2 taken in the inner shelf off the Hon Gom Peninsula provide ages of 0.42 and 0.84 ka BP (Figs. 3 and 4). Radiocarbon dating of the sediment core (core 01) at a water depth of $134 \mathrm{~m}$ covers the age interval of 2.29 to $10.78 \mathrm{ka} \mathrm{BP}$ (Figs. 3 and 4). Another core station (core 97) shows ages of highstand deposits ranging from 3.87 to 5.04 ky BP (Figs. 3 and 4). However, the age of the MFS on the Nha Trang shelf remains un- clear since it has not been dated. Previous studies on the Nha Trang and Sunda shelves have indicated a deglacial transgression from the last glacial maximum (LGM) sea-level lowstand termination at $19.6 \mathrm{ka} \mathrm{BP}$ to approximately $8.0 \mathrm{ka} \mathrm{BP}$ (Hanebuth et al., 2000, 2002; Bui et al., 2014). On the Red River and Mekong River deltas, ages of the MFS have been identified approximately at 8.0 ka BP (Hori et al., 2004; Tamura et al., 2009; Tjallingii et al., 2010). Therefore, the onset of HST deposits on the Nha Trang shelf can be correlated to the initiation of the formation of these two deltas. In our calculation, we assume that the last highstand period on the Nha Tran shelf began approximately 8 ky BP.

\section{VOLUME OF SEDIMENT STORAGE ON THE SHELF}

The volume of sediment storage on the Nha Trang shelf over the last $8 \mathrm{ky} \mathrm{BP}$ is calculated based on seismic interpretation results (Fig. 3). The highstand thickness was obtained by subtracting the modern seabed from the MFS surface (Fig. 3). The sediment thickness, which is determined in two-way travel time, is consequently converted into metres based on an average sound velocity of $1550 \mathrm{~m} / \mathrm{s}$ (Bui et al., 2014). The HST deposits on the Nha Trang shelf form a north-south elongated mud-belt depocentre developing along the mid-shelf that tends to pinch out towards the inner and outer shelf (Fig. 5). As we can observe on the frequency distribution histogram, there are some negative values in the sediment thickness map that result from the irregularity of the interpolated data (Fig. 5). These data are of course not real and therefore they are neglected in the sediment thickness map. As shown on the frequency distribution, the average HST thickness is approximately $3 \mathrm{~m}$ (Fig. 5). 


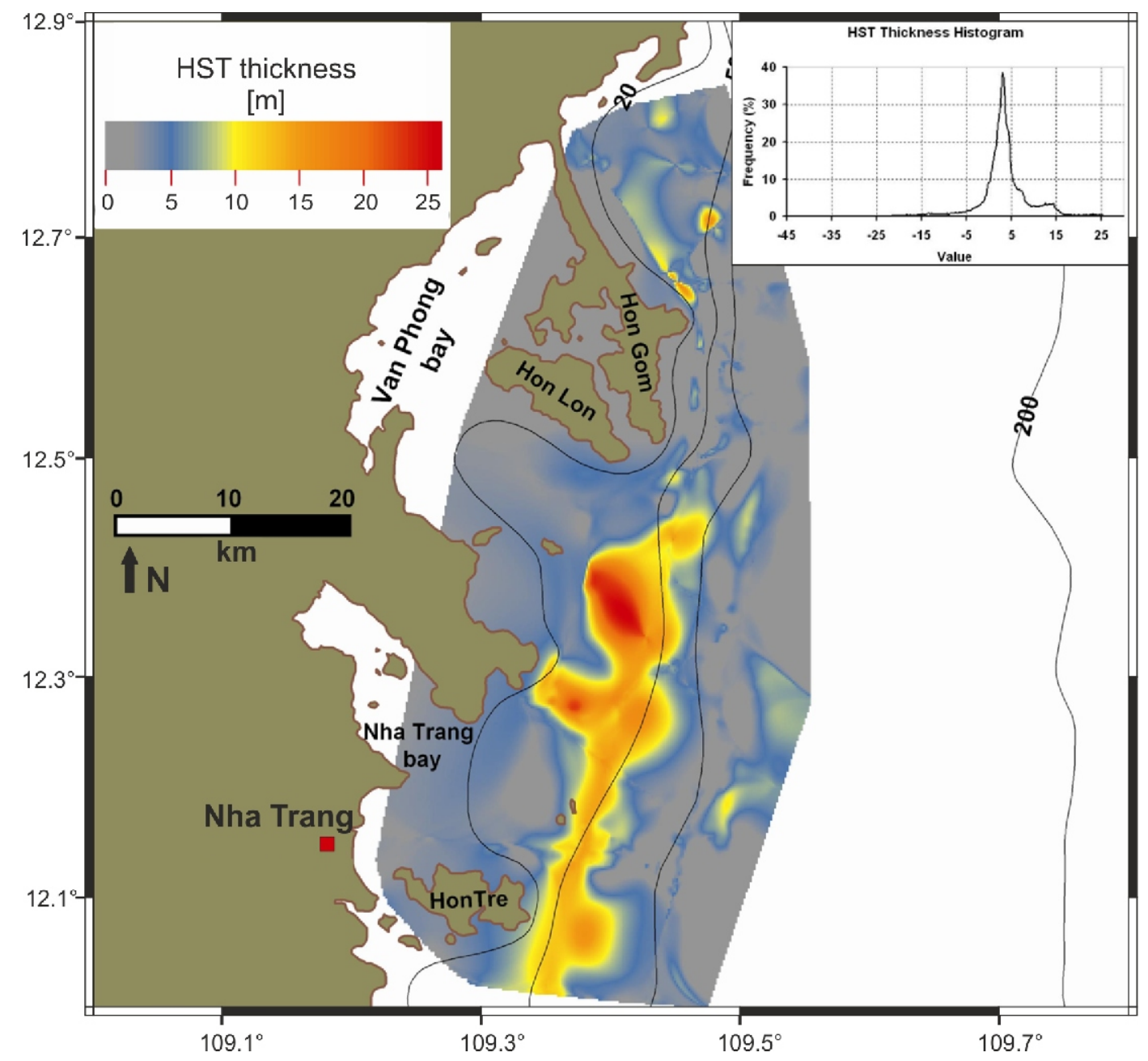

Fig. 5. Sediment thickness map and frequency distribution histogram of highstand deposits on the Nha Trang shelf (adapted from Bui et al., 2014)

Assuming a dry bulk density of $1.15 \mathrm{t} / \mathrm{m}^{3}$ (Schimanski and Stattegger, 2005a), we can roughly estimate the volume of modern HST sediments stored on the Nha Trang shelf as follows:

$$
\text { HST (8-0 ky BP): } \begin{gathered}
5000 \mathrm{~km}^{2} \times(3 \mathrm{~m} / 8000 \mathrm{y}) \times 1.15 \mathrm{t} / \mathrm{m}^{3}= \\
2.15 \mathrm{Mt} / \text { year }
\end{gathered}
$$

TOTAL SEDIMENT DISCHARGE TO THE SHELF

A previous study suggested that approximately $40-50 \%$ of the sediment supplied was stored on the central Vietnam shelf during the period of $7.6 \mathrm{ky} \mathrm{BP}$ to the present (Schimanski and Stattegger, 2005a). With inverse calculation based on the above percentage of sediment preserved on the shelf, we can estimate the annual sediment discharge to the Nha Trang shelf during the HST period (8 ky BP to present) as follows:

$$
(2.15 \times 100) /(50 \text { to } 40)=4.3 \text { to } 5.4 \mathrm{Mt} / \text { year. }
$$

\section{DISCUSSION}

The calculations of sediment discharge by the three local rivers entering the Nha Trang shelf in the previous section are basically performed on the present-day parameters (Tables 1 and 2). However, previous research on the nearby area of the SCS suggests that after $8 \mathrm{ky} \mathrm{BP}$, the paleo-coastline nearly reached its modern position and the temperature was more or less stable (Steinke et al., 2003; Shintani et al., 2008). Therefore, our calculation based on the modern drainage basin parameters and temperature represents the average value over the HST period. The uncertainty of calculation using the BSQT equation (Table 2) lies in the variability of discharge and human impacts, which can significantly modify the results. However, at 


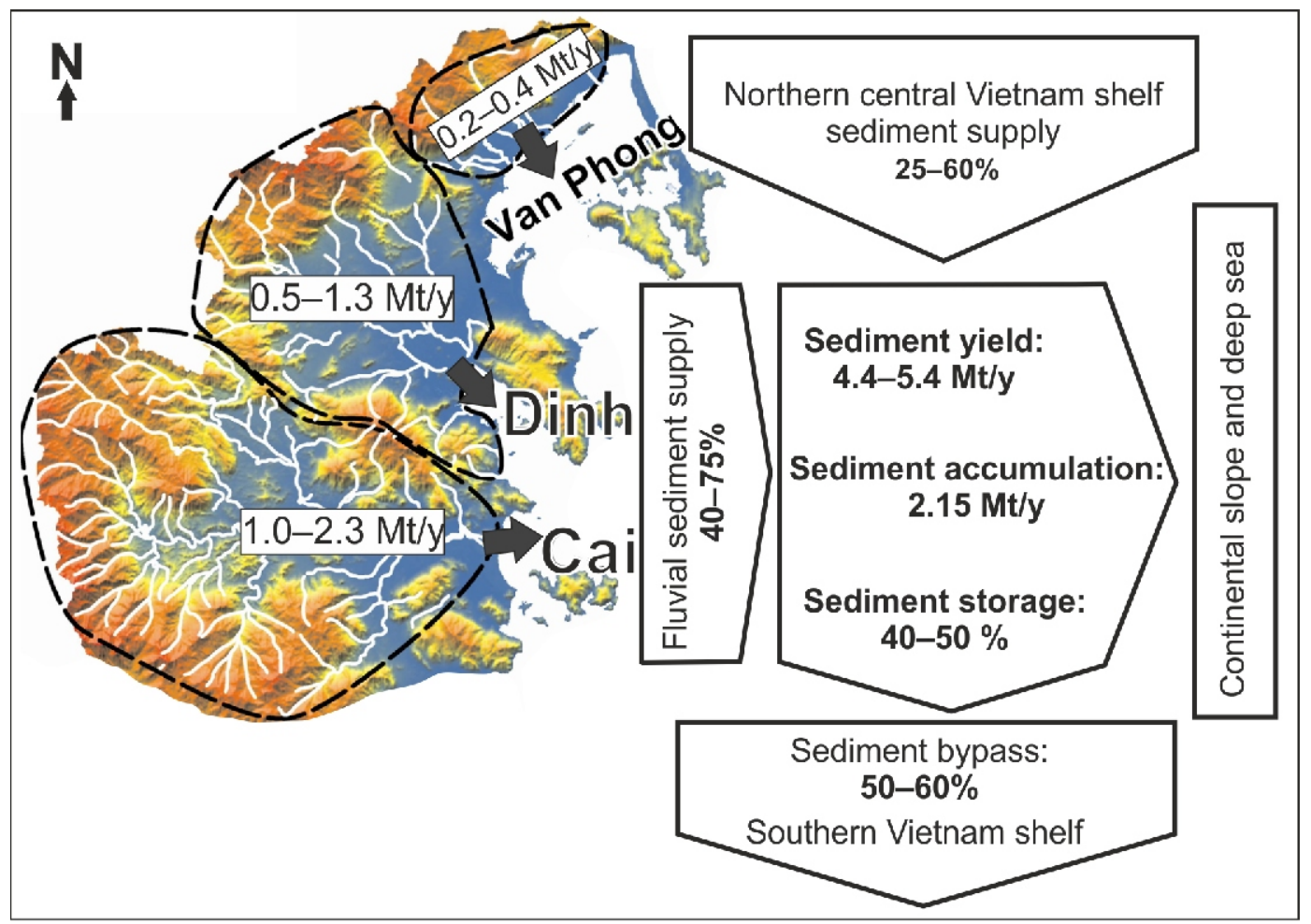

Fig. 6. A sediment budget for the Nha Trang shelf over the last highstand period

this stage of the research, human impact factors such as deforestation or dam construction are not included in the calculation.

The net sediment that accumulated on the Nha Trang shelf calculated from seismic data is probably lower than the published results of the Holocene sedimentation rate on the central Vietnam shelf (Schimanski and Stattegger, 2005a, b; Szczuciński et al., 2009). Schimanski and Stattegger (2005a, b) indicated that the Holocene sedimentation rate on the central Vietnam shelf is in the range of $5-10$ and $25-40 \mathrm{~cm} / \mathrm{ky}$ by using the AMS ${ }^{14} \mathrm{C}$ dating method. Another study of Szczuciński et al. (2009) using the ${ }^{210} \mathrm{~Pb}$ radioactive isotopes method suggested that the rates of recent sedimentation (less than 100 years) on the central Vietnam shelf range from 220 to $470 \mathrm{~cm} / \mathrm{ky}$. Nevertheless, the results of the above studies were calculated on sediment core data taken on the mid-shelf sediment depocentre or in areas where sediments are probable. In contrast, our calculation is based on seismic data that include the exposed bedrock and areas without sediment deposition, which therefore results in the lower estimate.

Comparison of the discharge of sediment supply by the three local river basins (1.7 to $4.0 \mathrm{Mt} /$ year) to the amount of sediment discharge to the Nha Trang shelf (4.3 to $5.4 \mathrm{Mt} / \mathrm{year}$ ) suggests that the local rivers can only account for approximately $40-75 \%$ of the total sediment supply to the shelf. The HST sediment thickness distribution (Fig. 5) reveals an elongated sediment depocentre located in front of the local river mouths. The position of the sediment depocentre suggests the importance of those rivers acting as the primary sediment supply sources to the shelf whereas the elongated shape indicates a generally southwards directed sediment transport by along-shore coastal currents (Trinh et al., 1979; Bui and Le, 2000; Nguyen et al., 2000a, b; Nguyen and Tong, 2000). Taking the above discussion into consideration, we speculate that the upper estimated value seems to be more reasonable and that the local rivers can contribute up to $75 \%$ of total sediment discharge to the Nha Trang shelf (Fig. 6). Nevertheless, sediment supply from the adjacent northern shelf region by along-shore transport can also be very significant (approximately $25 \%$ or more of total sediment supply), since the thickest sediments are found in front of the Van Phong River mouth (Figs. 5 and 6). The HST deposits are mostly deposited on the mid-shelf and they tend to thin out toward the outer shelf (Fig. 3). This suggests that the volume of highstand deposits transported to the continental slope is insignificant. In addition, previous studies indicate that the major portion of sediment supply to the Nha Trang shelf occurs during the rainy season (September to December). The sediments are then transported along-shore southwards by the dominant north-east monsoon effects (Nguyen, 2004; Barthel et al., 2009). We therefore speculate that approximately $50 \%$ of total sediment supply to the Nha Trang shelf is probably transported along-shore to the south (Fig. 6).

COMPARISON BETWEEN HIGHSTAND DEPOSITS

OF THE NHA TRANG SHELF AND SURROUNDING AREAS

The sediment budget model of highstand deposits on the Nha Trang shelf is an example of small mountainous river basins, and it is significantly different from that of the large river delta systems in Vietnam such as the Mekong and Red rivers (Figs. 1 and 7). On the wide and low gradient shelves off the SE 


Inner shelf Middle shelf Outer shelf

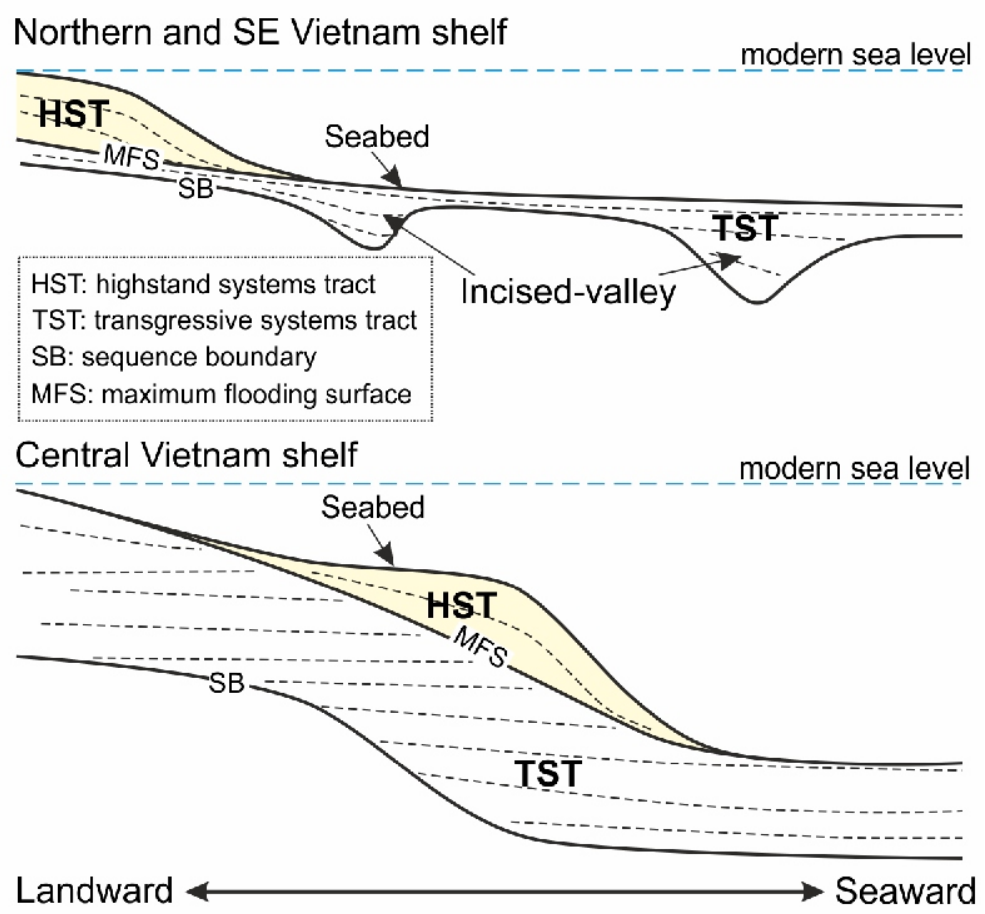

Fig. 7. Comparison between the Holocene sequence stratigraphic model of the narrow shelf off Nha Trang and the wide-low gradient shelf off the SE and northern Vietnam (Bui et al., 2013; Bui et al., 2014; Nguyen et al., 2018)

(Mekong River delta) and northern Vietnam (Red River delta), a thick highstand (HST) wedge is confined to the inner shelf leaving the mid and outer shelf in a starved condition (Bui et al., 2013; Nguyen et al., 2018). Nevertheless, the HST depocentre on the narrow central Vietnam shelf is located on the mid-shelf forming a clinoform and it thins toward the inner and outer shelf (Bui et al., 2014). Such clinoforms are often found in the down-drift direction of river mouths and may extend over several hundred kilometres (Liu et al., 2004; Pratson et al., 2009). The highstand sediment budget models of these two types of continental shelf (Fig. 7) show distinctive features which result from the differences in sediment supply regime, shelf morphology and hydrodynamic conditions between the two areas (Bui et al., 2013, 2014).

\section{CONCLUSION}

A sediment budget over the last deglacial highstand period for the Nha Trang shelf is presented and discussed. There are still uncertainties in our calculation that suggest further study should be continued to improve the results. However, the results of this study have some implications for the flux and fate of sediments leaving small mountainous rivers in central Vietnam. The results and discussion above suggest some conclusions for the research:

- the annual suspended sediment discharge to the Nha Trang shelf during the highstand period from $8 \mathrm{ky} \mathrm{BP}$ to present ranges from: 4.3 to $5.4 \mathrm{Mt} /$ year;
- the discharge of sediment to the Nha Trang shelf by the three local rivers: the Cai, Dinh and Van Phong range between 1.7-4 Mt/year, in which the proportions of those rivers are as follows: the Cai $60 \%$, the Dinh $30 \%$ and the Van Phong 10\%. Other sources of sediment supply to the Nha Trang shelf are probably transported along-shore from the nearby shelves;

- the net sediment volume storage on the Nha Trang shelf is approximately $2.15 \mathrm{Mt} /$ year. Approximately half of total supplied sediment to the shelf is transported along-shore to the southern Vietnam shelf;

- the flux and fate of sediments escaping small mountainous rivers off Nha Trang is significantly different from that of the huge river delta systems in Vietnam such as the Mekong and Red Rivers.

Acknowledgments. This research is based on a doctoral dissertation submitted to the University of Kiel (https://d-nb.info/1013154398/34). Data used for this study were extracted from the results of long-term cooperation in marine research between Vietnam and Germany funded by Deutsche Forschungsgemeinschaft (DFG, grant Sta 401/10) and the Ministry of Science and Technology (MOST), Vietnam. This study was supported by the Vietnam National Project KC09 04/16-20. We would like to thank the editor and reviewers for their constructive comments on our manuscript. 


\section{REFERENCES}

Barthel, K., Rosland, R., Thai, N.C., 2009. Modelling the circulation on the continental shelf of the province Khanh Hoa in Vietnam. Journal of Marine Systems, 77: 89-113.

Brommer, M., 2009. Mass-balanced stratigraphy Data-model comparison within a closed sedimentary system (Adriatic Sea, Italy). Ph.D. thesis, Delft University.

Bui, H.L., Le, D.M., 2000. Features of wave field, its effect to erosion - deposition processes in the Cudai (Hoian), Cai River mouth (Nha Trang) and Phanthiet Bay in typical local wind conditions. Collection of Marine Research Works, 10: 21-33.

Bui, V.D., Stattegger, K., Phung, V.P., Nguyen, T.T., 2013. Late Pleistocene-Holocene seismic stratigraphy on the South East Vietnam Shelf. Global and Planetary Change, 110, Part B: 156-169.

Bui, V.D., Stattegger, K., Nguyen, T.T., Phung, V.P., Tran, T.D., Bui, X.T., 2014. Late Pleistocene-Holocene seismic stratigraphy of Nha Trang shelf, Central Vietnam. Marine and Petroleum Geology, 58, Part B: 789-800.

Catuneanu, O., 2002. Sequence stratigraphy of clastic systems: concepts, merits, and pitfalls. Journal of African Earth Sciences, 35: 1-43.

Catuneanu, O., 2009. Towards the standardization of sequence stratigraphy. Earth-Science Reviews, 92: 1-33.

Emch, M., Feldacker, C., Yunus, M., Streatfi eld, P.K., Thiem, V.D., Canh, D.G., Ali, M., 2008. Local environmental drivers of cholera in Bangladesh and Vietnam. American Journal of Tropical Medicine and Hygiene, 78: 823-832.

Grant, J.A., Schreiber, R., 1990. Modern swathe sounding and sub-bottom profiling technology for research applications: the Atlas Hydrosweep and Parasound Systems. Marine Geophysical Research, 12: 9-19.

Hanebuth, T.J.J., Stattegger, K., Grootes, P.M., 2000. Rapid flooding of the Sunda Shelf: a Late Glacial sea-level record. Science, 288: 1033-1035.

Hanebuth, T.J.J., Stattegger, K., Saito, Y., 2002. The stratigraphic architecture of the central Sunda Shelf (SE Asia) recorded by shallow-seismic surveying. Geo-Marine Letters, 22: 86-94.

Hanoi Marine Hydro Meteorological Center, 2004. Bang Thuy Trien 2004 Tap II (Tide Tables Vol. I, in Vietnamese)

Hori, K., Tanabe, S., Saito, Y., Haruyama, S., Nguyen, V., Kitamura, A., 2004. Delta initiation and Holocene sea-level change: Example from the Song Hong (Red River) delta, Vietnam. Sedimentary Geolology, 164: 237-249.

Liu, J.P., Milliman, J.D., Gao, S., Cheng, P., 2004. Holocene development of the Yellow iver's subaqueous delta, North Yellow Sea. Marine Geology, 209: 45-67.

Milliman, J.D., Syvitski, P.M., 1992. Geomorphic/tectonic control of sediment discharge to the ocean: the importance of small mountainous rivers. Journal of Geology, 100: 525-544.

Milliman, J.D., 1995. Sediment discharge to the ocean from small mountainous rivers: the New Guinean example. Geo-Marine Letters, 15: 127-133.

Nguyen, B.X., Tong, P.H.S., 2000. The characteristics of distribution and change of the seawater temperature and salinity of $\mathrm{Ca}$ River Estuary and northern part of Nha Trang Bay in dry and rainy seasons. Collection of Marine Research Works, 10:14-20.

Nguyen, L.D., 2004. Research on the preventative method of flooding processes on the central Vietnam (in Vietnamese). National Project KC08.12.

Nguyen, T.A., Vo, D.S., Phan, M.T., Nguyen, H.H., Ittekkot, V., 2000a. Tracing sediment transport and bed regime in Nha Trang Bay. Collection of Marine Research Works, 10: 63-69.

Nguyen, V.L., Ta, T.K.O., Tateishi, M., 2000b. Late Holocene depositional environments and coastal evolution of the Mekong
River Delta, Southern Vietnam. Journal of Asian Earth Sciences, 18: 427-439.

Nguyen, T.T., Paul, J.L., Mai, D.D., Dang, H.N., Do, H.C., Bui, V.D., P.V. P., Tran, D.T., Duong, Q.H., Ngo, T.N., 2018. Late Pleistocene-Holocene sequence stratigraphy of the subaqueous Red River delta and the adjacent shelf. Vietnam Journal of Earth Science, 40: 271-287.

Pratson, L.F., Nittrouer, C.A., Wiberg, P.L., 2009. Seascape evolution on clastic continental shelves and slopes. In: Continental Margin Sedimentation: From Sediment Transport to Sequence Stratigraphy (eds. C.A. Nittrouer, J.A. Austin, M.E. Field, J.H Kravitz, J.P.M. Syvitski and P.L. Wiberg), 37: 339-384. Blackwell Publishing Ltd., Oxford, UK.

Schimanski, A., Stattegger, K., 2005a. A conceptual sediment budget for the Vietnam Shelf. Meyniana, 57: 101-115.

Schimanski, A., Stattegger, K., 2005b. Deglacial and Holocene evolution of the Vietnam shelf: stratigraphy, sediments and sea-level change. Marine Geology, 214: 365-387.

Shintani, T., Yamamoto, M., Chen, M.T., 2008. Slow warming of the northern South China Sea during the last deglaciation. Terrestrial, Atmospheric and Oceanic sciences Journal, 19: 341-346.

Steinke, S., Kienast, M., Hanebuth, T.J.J., 2003. On the significance of sea-level variations and shelf paleo-morphology in governing sedimentation in the southern South China Sea during the last deglaciation. Marine Geology, 201:179-206.

Syvitski, J.P.M., Milliman, J.D., 2007. Geology, geography and humans battle for dominance over the delivery of sediment to the coastal ocean. Journal Geology, 115: 1-19.

Szczuciński, W., Jagodziński, R., Nguyen, T.T., Kubicki, A., Stattegger, K., 2005. Sediment dynamics and hydrodynamics during a low river discharge conditions in Nha Trang Bay, Vietnam. Meyniana, 57: 117-132.

Szczuciński, W., Stattegger, K., Schloten, J., 2009. Modern sediments and sediment accumulation rates on the narrow shelf off central Vietnam, South China Sea. Geo-Marine Letters, 29: 47-59

Ta, T.K.O., Nguyen, V.L., Tateishi, M., Kobayashi, I., Saito, Y., 2001. Sedimentary facies, diatom and foraminifer assemblages in a late Pleistocene-Holocene incised-valley sequence from the Mekong River delta, Bentre Province, southern Vietnam; the BT2 core. Journal of Asian Earth Sciences, 20: 83-94.

Tamura, T., Saito, Y., Sieng, S., Ben, B., Kong, M., Sim, I., Choup, S., Akiba, F., 2009. Initiation of the Mekong River delta at 8 ky: evidence from the sedimentary succession in the Cambodian lowland, Quaternary Science Reviews, 28: 327-344.

Tran, D.T., Saito, Y., Dinh, V.H., Nguyen, V.L., Ta, T.K.O., Tateishi, M., 2004. Regimes of human and climate impacts on coastal changes in Vietnam. Regional Environmental Change, 4: 49-62.

Tjallingii, R., Stattegger, K., Wetzel, A., Van Phach, P., 2010. Infilling and flooding of the Mekong River incised valley during deglacial sea-level rise. Quaternary Science Reviews, 29: 1432-1444.

Trinh, P., Pham, V.T., Nguyen, T.S., Trinh, T.H., Tran, H., Tran, D.T., Nguyen, H.S., 1979. Geomorphological and sedimentological characteristic of Binhcang - Nhatrang Bay (in Vietnamese). Collection of Marine Research Works, 1: 77-92.

Wiesner, M., 1999. Cruise Report SONNE 140 SÜDMEER III. Reports Institut für Geowissenschaften, 7.

Wiesner, M., 2006. Cruise Report RV Sonne 187 VIETNAM. Berichte - Reports No. 23. Institut für Geowissenschaften Universität, Kiel. 